\title{
PENYULUHAN KEMASAN DAN MEREK PADA ROTI GORENG LUMER DI BANDUNG
}

\author{
Febri Rakhmawati ARSJ \\ Perbanas Institute \\ Jl. Perbanas, Kuningan, Jakarta Selatan \\ Email Korespondensi : febirakhma@gmail.com
}

\begin{abstract}
ABSTRAK
Wabah pandemi Covid-19 telah mempengaruhi semua sektor ekonomi termasuk industri kreatif. Hal tersebut tidak luput menimpa kota Bandung. Kota Bandung menjadi pelopor industri kreatif di tanah air karena banyaknya karya kreatif yang dihasilkan dan menjadi tren di Indonesia, terutama di kalangan generasi muda. Industri kreatif yang berkembang di Kota Bandung memberikan kontribusi yang signifikan. Tak banyak yang tahu, ada sekitar 144 unit industri kreatif di Kecamatan Buah Batu, Kota Bandung. Jumlah tersebut tersebar di seluruh wilayah kecamatan, mulai dari Kelurahan Cijawura, Margasari, Jatisari, sampai Sekejati. Jenis produksinya pun beragam, mulai dari kuliner, fesyen, hingga kerajinan tangan .
\end{abstract}

Kata kunci : Bandung, Industri kreatif, Makanan

\begin{abstract}
The Covid-19 pandemic outbreak has affected all sectors of the economy including the creative industry. This did not escape the city of Bandung. The city of Bandung has become the pioneer of the creative industry in the country because of the many creative works that have been produced and have become a trend in Indonesia, especially among the younger generation. The creative industry that is developing in the city of Bandung makes a significant contribution. Not many know, there are about 144 creative industry units in Buah Batu District, Bandung City. This number is spread throughout the sub-district, starting from Cijawura, Margasari, Jatisari, to Sekejati Villages. The types of production also vary, from culinary, fashion, to handicrafts.
\end{abstract}

Keywords: Bandung, Creative Industry, Food 


\section{PENDAHULUAN}

Virus corona menjadi topik terhangat sejak memasuki awal tahun 2020 tepatnya pada 20 Januari di kota Wuhan provinsi Hubei, Tiongkok. Virus ini mendadak menjadi terror menakutkan bagi masyarakat dunia, terutama setelah merenggut nyawa ratusan orang hanya dalam waktu dua pekan. Wabah pandemic virus corona ( Covid 19) telah berdampak banyak terhadap sendi-sendi kehidupan. Selain faktor kesehatan, penyebaran virus mematikan ini juga berpengaruh besar pada pertumbuhan ekonomi global. Dampak dari pandemic virus corona merambah ke segala aspek terutama pada sector perekonomian Indonesia sehingga pertumbuhan ekonomi menjadi sangat tidak stabil.

Industri yang paling merasakan dampaknya yakni industri kreatif. Hal ini dirasakan pula oleh kota Bandung yang merupakan salah satu barometer industri kreatif di Indonesia. Hal itu berkat beragam produk kreatif yang lahir di Kota Bandung. Industri kreatif masih akan menjadi andalan Jawa Barat dalam menggerakkan ekonomi memasuki fase kenormalan baru atau di Jabar disebut Adaptasi Kebiasaan Baru (AKB). 60 persen industri nasional ada di Jabar, penduduk Jabar paling banyak, market size ada di Jabar. Jabar punya potensi sangat memadai untuk mengembangkan industri kreatif di era normal baru. Industri-industri kreatif di Kota Bandung memang sedang tumbuh cukup pesat. Terlebih lagi, Kota Bandung merupakan kota wisata dengan pertumbuhan ekonomi 7,8\%.

Tak banyak yang tahu, ada 144 unit industri di Kecamatan Buahbatu, Kota Bandung. Jumlah tersebut tersebar di seluruh wilayah kecamatan, mulai dari Kelurahan Cijawura, Margasari, Jatisari, sampai Sekejati. Jenis produksinya pun beragam, mulai dari kuliner, fesyen, hingga kerajinan tangan.Menurut Camat Buah batu, Deny Sany mengatakan, ada 36 industri yang menjadi produk unggulan Kecamatan Buah batu. Industri-industri tersebut merupakan hasil binaan dari Wirausaha Baru Kota Bandung. Setiap daerah ingin agar produk-produk asal daerah memiliki kekuatan, terutama di pasar dalam negeri. Hal ini membuatnya optimis industri kreatif di Kota Bandung akan terus berkembang.

Penjualan secara daring (online) dan e-commerce pun akan sangat berkembang yang juga masuk bagian industri kreatif, tergantung bagaimana dia men-delivered barang jualannya dengan cara tidak biasa," jelas Tita yang juga Ketua Bandung Creatif City Forum (BCCF).

Salah satu industri kreatif yang ada di kota Bandung adalah usaha kuliner khususnya cemilan buat di rumah berupa roti goreng. Roti goreng lumer masih terbatas dalam melakukan pemasarannya dikarenakan belum menggunakan media online serta pengemasan yang masih sederhana dan belum memiliki merek.

\section{METODOLOGI}

\section{Pelaksanaan}

Kegiatan ini dilaksanakan di rumah pemilik roti goreng lumer, yang beralamatkan di komplek Palem 1 Residence, Terusan Buah Batu Bandung. Kegiatan ini di laksanakan pada:

Hari/tanggal : Selasa, 1 September 2020

Waktu : Pukul 9.00-15.30

Tempat : : Komplek Palem 1Residence, Buah Batu Bandung

Agenda $\quad$ : Penyuluhan desain kemasan dan merek 


\section{Sasaran}

Sasaran dari kegiatan pengabdian masyarakat ini adalah memberikan tampilan kemasan yang lebih menarik beserta adanya merek yang dapat membedakan roti gorenng lumer dengan para pesaingnya.

\section{METODE KEGIATAN}

\section{Wawancara}

Teknik pengumpulan data awal yang dilakukan dalam pengabdian kepada masyarakat ini dilakukan dengan cara tanya jawab langsung kepada pemilik roti goreng lumer (Mba Nuna). Pertanyaan terdiri dari ide awal membuat usaha roti goreng, kemasan yang menarik sampai alasan tidak memberikan merek pada roti goreng yang dibuatnya. 2. 2. Presentasi dan Diskusi

Selain metode wawancara, metode lain yang dilakukan pada saat pengabdian masyarakat adalah presentasi serta diskusi. Presentasi dilakukan dengan menampilkan power point berupa teoritis mengenai kemasan. Berikutnya diskusi di lakukan dengan menanyakan kendala-kendala yang dihadapi dalam memasarkan roti goreng lumer.

\section{Kerangka Pemecahan Masalah}

Berdasarkan hasil pemaparan materi dan diskusi, ada beberapa permasalahan yang bisa diselesaikan. Pertama, kemasan roti goreng lumer diganti dengan plastik bening yang lebih tebal yakni 100 mikron agar plastik roti goreng jika terjatuh tidak langsung pecah serta di tutup dengan cara di press. Kedua, pemberian merek dan label pada kemasan roti dengan merek roti goreng lumer. Dengan jenis font warna merah yang berarti menggugah selera konsumen untuk mencoba dan akhirnya tertarik untuk membeli roti gorengnya dan menambahkan pemberian tagline: nagih bangett. Ketiga, memberikan penjelasan mengenai pentingnya menggunakan digital marketing seperti market place ( tokopedia, shopee dll ) maupun platform e commerce ( whatsapp grup, Instagram maupun facebook ). Keempat, memberikan pengarahan dan pendampingan langsung menggunakan digital marketing mulai dari membuat account di media sosial, mengambil gambar yang menarik sehingga content terlihat konsumen penasaran, hingga gambar tersebut di posting di account media social.

\section{Realisasi Pemecahan Masalah}

Upaya yang dilakukan dalam menyelesaikan masalah di dalam usha roti gorng lumer setelah dilakukan wawancara awal diikuti dengan diskusi ditemukan penigkatan pengetahuan mengenai pentingnya kemasan primary agak tebal yang membungkus roti goreng lumer. Yang tak kalah penting juga adalah pemberian nama aatau merek pada roti goreng sert label. Tujuan pemberian nama roti goreng dibuat agar menjadi pembeda dengan merek-merek roti goreng yang sudah ada di pasaraan daan memudahkan konsumen mengingat roti goreng kita. Selanjutnya dengan rajin mengupload content yang menarik di dalam media sosial minimal sehari sekali akan banyak di respon oleh khalayak luas dan dapat menambah pemasaran roti goreng lumer. 
Tabel 1. Jadwal penyuluhan desain kemasan dan merek, Selasa 1 September 2020

\begin{tabular}{|c|c|c|}
\hline Waktu & Uraian Kegiatan & Metode Pelaksanaan \\
\hline $09.00-09.15$ & Persiapan & \\
\hline $09.15-12.00$ & $\begin{array}{l}\text { Materi sesi } 1 \\
\text { Pengenalan kemasan } \\
\text { secondary daan shipping) }\end{array}$ & Presentasi dan diskusi \\
\hline $12.00-13.00$ & Ishoma & \\
\hline $13.00-14.30$ & $\begin{array}{l}\text { Materi sesi } 2 \\
\text { Pemberian merek dan label }\end{array}$ & Presentasi dan diskusi \\
\hline $14.30-15.30$ & $\begin{array}{l}\text { Materi sesi } 3 \\
\text { Digital mareting }\end{array}$ & $\begin{array}{l}\text { Presentasi, diskusi } \\
\text { serta pendampingan }\end{array}$ \\
\hline $15.30-15.45$ & Penutupan & \\
\hline
\end{tabular}

\section{HASIL DAN PEMBAHASAN}

Kegiatan pengabdian kepada masyarakat dalam bentuk kemitraan ini dilaksanakan oleh dosen Perbanas Institute. Adapun hasil kegiatan dilakukan sebagai berikut:

1. Sosialisasi kemasan pada roti goreng

Program pertama pengabdian kepada masyarakat yakni dengan memberikan sentuhan baru pada kemasan agar terlihat lebih menarik. Tetapi tidak melupakan fungsi utama dari kemasan yakni melindungi produk (roti goreng) agar tetap dalam kondisi baik. Menurut Aaker kemasan yakni kegiatan merancang dan memproduksi wadah atau bungkus sebagai sebuah produk. Namun, sekarang kemasan menjadi faktor yang cukup penting sebagai alat pemasaran. Kemasan yang dirancang dengan baik dapat membangun ekuitas merek dan mendorong penjualan. Kemasan adalah bagian pertama produk yang dihadapi pembeli dan mampu menarik atau menyingkirkan pembeli. Pengemasan suatu produk biasanya dilakukan oleh produsen untuk dapat merebut minat konsumen terhadap pembelian barang. Produsen berusaha memberikan kesan yang baik pada kemasan produknya dan menciptakan model kemasan baru yang berbeda dengan produsen lain yang memproduksi produk-produk sejenis dalam pasar yang sama. Roti goreng memiliki 3 tingkatan kemasan mulai dari primary packaging berupa plastik bening dengan ketebalan 100 mikron yang dapat melindungi roti goreng lebih kuat dan tahan lama dan di tutup dengan cara di press seal. Warna bening pada kemasan bermakna bahwa produk yakni roti goreng dapat terlihat jelas dari kemasan sehingga calon konsumen yang akan membeli dapat mengetahui secara jelas isi dari kemasan tersebut. Ukuan plastik yakni 20 x $30 \mathrm{~cm}$. Tingkatan kedua yakni secondary packaging berupa plastik tipis yang di bungkus per masing-masing roti dengan di susun polanya secara selang seling yang bertujuan agar roti tidak saling menempel satu sama lain.Ukuran plastiknya $10 \times 20 \mathrm{~cm}$. Sedangkan kemasan terakhir yakni shiping maksudnya ketika konsumen membeli 1 pack dan 
langsung datang ke rumah mba Nuna roti di bungkus lagi menggunakan plastik kresek ataupun ketika membeli dalam jumlah banyak di shipping bisa menggunakan dus ataupun plastik tebal. Gambar berikut ini merupakan dokumentasi pengemasan di awal dan setelah adanya penyuluhan.

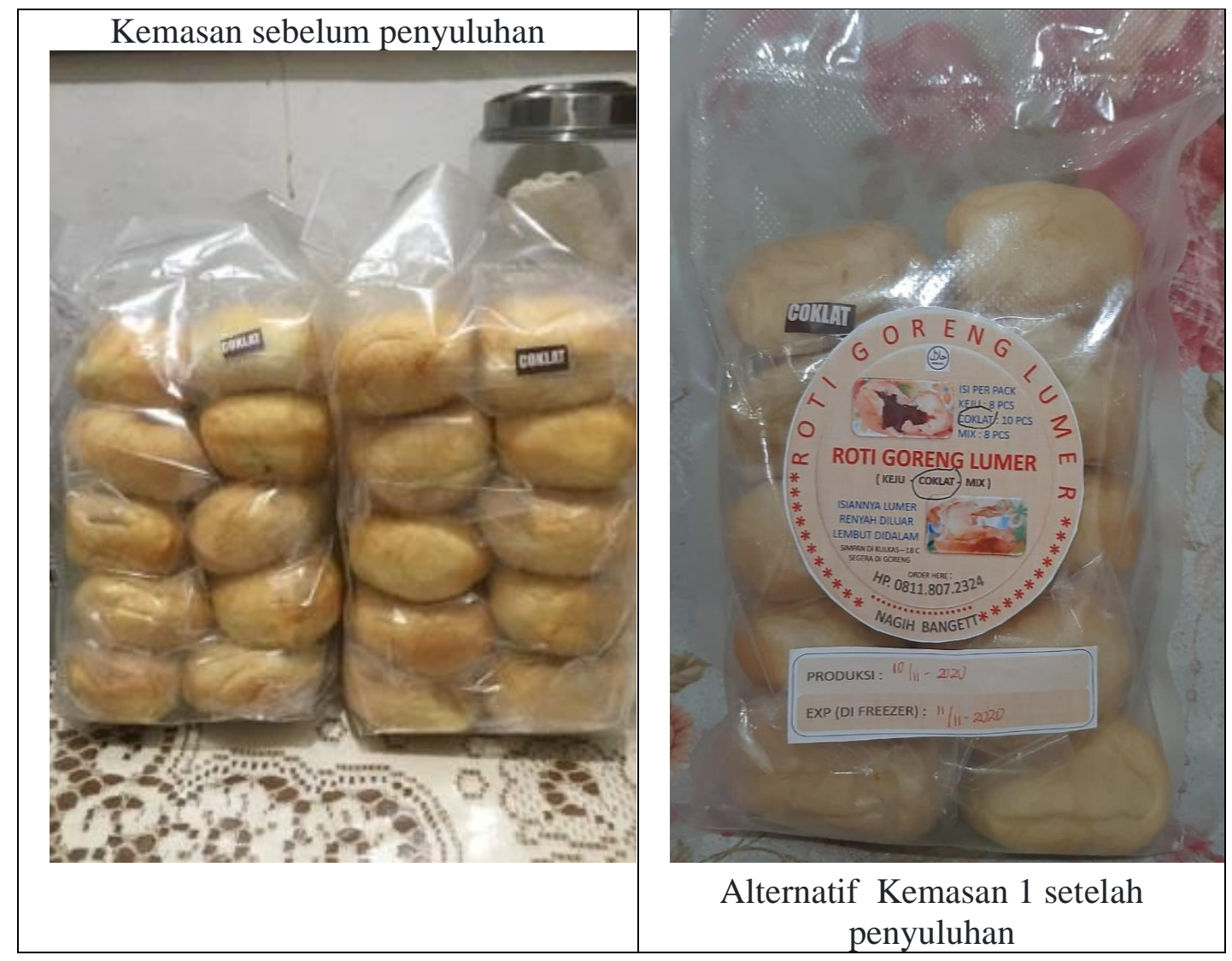




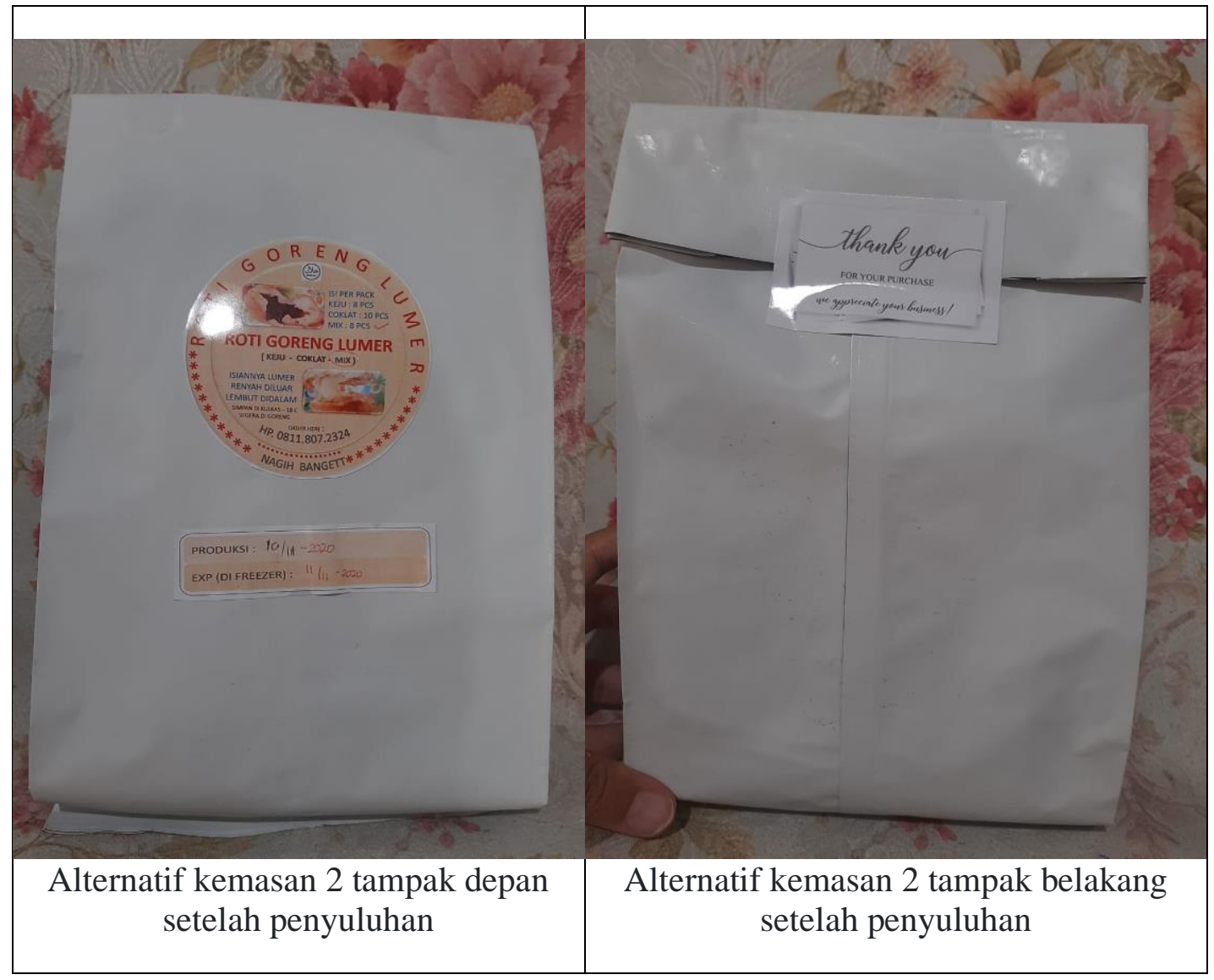

2. Sosialisasi Merek dan Label

Selanjutnya penjelasan sosialisai mengenai merek. Merek menurut Kotler dan Amstrong adalah symbol, tanda, rancangan ataupun kombinasi dari tiga tersebut yang ditunjukkan sebagai identitas dari penjual yang kemudian dijadikan pembeda dengan pesaing yang ada di pasaran. Sebelum ada pelatihan, roti goreng milik Mba Nuna tidak memiliki merek. Sekarang setelah adanya pelatihan, Mba Nuna tertarik untuk membuat sebuah merek untuk usaha roti gorengnya. Mba Nuna memberikan merek dengan nama "roti greng lumer " agar mudah diingat oleh konsumen dan menjadi pembeda dengan para pesaing yang ada di pasaran. Selain memberikan merek Mba Nuna juga memberikan label sebagai tambahan infrmasi daari produknya. Menurut Kotler dan Amstrong, label adalah salah satu bagian dari produk berupa keterangan baik gambar maupun kata-kata yang berfungsi sebagai sumber informasi produk dan penjual. Label umumnya berisi informasi berupa nama atau merek produk, bahan baku, bahan tambahan komposisi, informasi gizi, tanggal kedaluwarsa, isi produk dan keterangan legalitas. Menurut Kotler dan Amstrong Label terdiri dari open date production, harga dan bahan baku. Dalam label roti goreng lumer hanya memberikan informasi berupaa tanggal produksi dan expired roti goreng. Roti goreng lumer dapat bertahan selama satu bulan di dalam kulkas. Gambar berikut ini merupakan dokumentasi label di awal dan setelah adanya penyuluhan. 


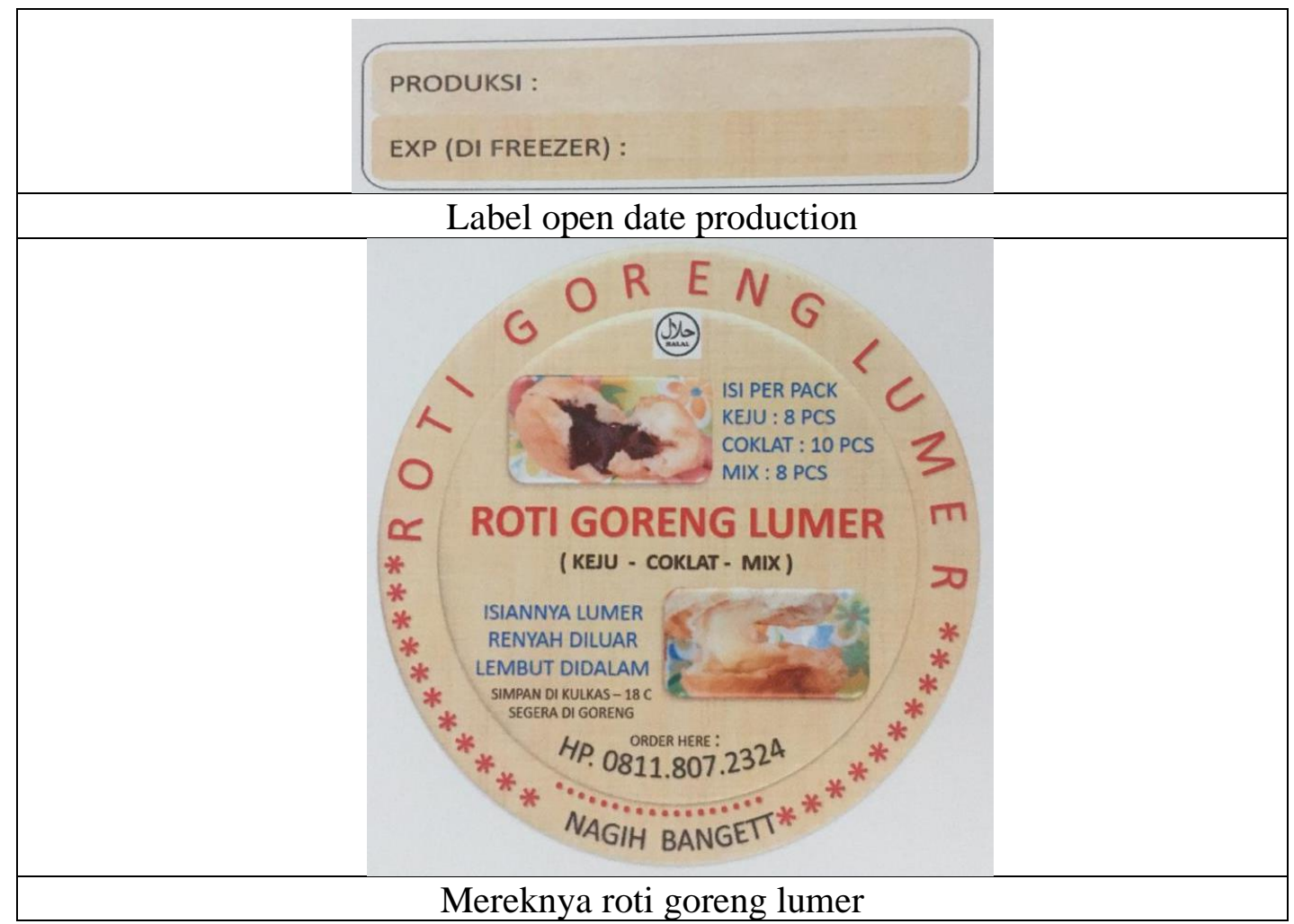

3. Sosialisasi tentang penggunaan digital marketing

Program pengabdian masyarakat selanjutnya adalah sosialisasi penggunaan dgital marketing dengan membuat account di facebook dan instagram. Pemilihan facebok dengan instagram dikarenakan 2 market place ini paling berpotensi dalam meraih calon kosumen baru. Mba Nuna juga sering lebih rajin mengupdate staatusnya di whatsapp dengan berisikan content dan gambar yang lebih menarik dari roti goreng lumer minimal sekali dalam sehari serta menampilkaan review dari konsumen yang sudah mencoba roti goreng lumer. Hasil kegiatan yang dilakukan menujukkan peningkatan pengetahuan dan penjualan mitra sebesar $70 \%$. Hal ini dipantau sebelum aadaya pelatihan dan sesudah dilaksanakan pelaatihan. Kegiatan ini membutuhkan pelatihan lebih lanjut lagi kepada mitra.

Program pengabdian kepada masyarakat ini berlangsung dengan baik. Kegiatan ini meliputi peyuluhan mengenai pengemasan ulang, pemberian merek dan label serta membuat digital marketing di whatsapp, facebook serta instagram. Diharapkan mitra selalu konsisten dalam melakukan pemaasaran roti goreng lumernya agar dapat memperluas pasar sasaran.. Terima kasih kepada Mba Nuna serta pihak terkait lain yang mendukung kegiatan pengabdian masyarakat ini dapat berlangsung dengan baik. 


\section{KESIMPULAN DAN SARAN}

\section{Kesimpulan}

Berdasarkan hasil sosialisasi mengenai pengemasan ulang, pemberian merek dan label serta membuat digital marketing dapat disimpulkan sebagai berikut:

1. Pemilik roti goreng lumer telah mendapatkan pengetahuan dan pemahaman tentang cara pengemasan dalam prduk roti goreng lumer.

2. Pemilik roti goreng lumer telah mendapatkan pengetahuan dan pemahaman pentingnya sebuah merek dn label pada roti goreng lumer.

3. Pemahaman mengenai penggunaan database untuk meningkatkan market share.

\section{Saran}

Saran setelah pelaksanaan kegiatan adalah sebagai berikut:

1. Mitra diharapkan dapat menerapkan straategi pemasaran dalam meraih caalon konsumen baru.

2. Adanya tindak lanjut pelatihan mengenai penggunaan digital marketing untuk menambah keahlian mitra.

\section{DAFTAR PUSTAKA}

Aaker David. (2014). Aaker On Branding: 20 Prinsip Esensial Mengelola dan Mengembangkan Brand. Jakarta : Gramedia.

Bandung industri kreatif. https://humas.bandung.go.id (diakses tanggal 26 Desember 2020)

Barometer industry kreatif. Htts://republika.co.id (diakses tanggal 26 Desember 2020)

Kotler and Amstrong. (20018). Principles of Marketing. Global Edition. Pearson. 